\title{
Did tuition fees in Germany constrain students' budgets? New evidence from a natural experiment
}

\author{
Stephan Thomsen ${ }^{1,2,3,4^{*}}$ and Friederike von Haaren-Giebel ${ }^{1,2}$
}

\author{
* Correspondence: thomsen@niw.de \\ ${ }^{1}$ NIW Hannover, Königstr. 53, \\ D-30175 Hannover, Germany \\ ${ }^{2}$ Leibniz Universität Hannover, \\ Hannover, Germany \\ Full list of author information is \\ available at the end of the article
}

\begin{abstract}
Less than a decade ago, several German states introduced tuition fees for university education. Despite their comparatively low level of about $€ 500$ per semester, fees were perceived by the public to increase social injustice and have been abolished recently. Whereas other studies have shown no effect on enrollment, we analyze the effects on students' budgets. To identify causal effects, we exploited the natural experiment established by the introduction of fees. Tuition fees decrease total expenditure moderately by about $4 \%$. With regard to financial resources, students are more likely to receive support from parents or take out a loan.
\end{abstract}

JEL codes: 122, I28, H75

Keywords: Tuition fees, Student spending, Natural experiment, Germany

\section{Introduction}

Tuition fees are a common method of (co-)financing university education in many countries, and their importance for financing higher education systems has increased in recent times. In Germany, students had to pay tuition fees until 1971, when they were abolished in response to the student movement of the 1960s. University studies were then free for more than 30 years, with only a low lump-sum subscription fee being charged for administrative and other purposes (Hetze and Winde 2012). After a change in law, however, federal states were allowed to grant permission to universities to charge tuition fees. Subsequently, seven of the 16 federal states (re-)introduced tuition fees of up to $€ 500$ per semester in 2007 with the aim of improving the quality of university teaching and studying conditions. This introduction was accompanied by highly controversial discussions, and after just a few years, the federal states reabolished the fees, with the last state (Lower Saxony) passing the resolution in 2013.

The main arguments put forward against tuition fees were the threat to equal opportunities and the possible deterrent effects on future students. However, reliable empirical studies did not find a negative effect of tuition fees on student enrollment in Germany (e.g., Helbig et al. 2012, Bruckmeier and Wigger 2014). Nevertheless, although enrollment behavior was not affected, the imposition of tuition fees still meant an additional financial burden. While average annual spending of a student in Germany during the 2000s amounted to about $€ 7600$ per 
year for rent, food, learning material, leisure, etc., the introduction of tuition fees implied further costs of $€ 1000$ or, on average, a $13 \%$ increase in costs. Hence, tuition fees may affect disposable funds available for consumption or saving. If students' expenditure matched their individual budget (constraint) previously, they would have had to increase their amount of disposable funds, for example, by increasing working hours. This may have had adverse effects on study duration or study performance. Obviously, if students were not that financially constrained, the imposition of the comparatively low tuition fees in Germany may not have affected spending behavior at all. The effect of the introduction of tuition fees therefore depends on the actual financial situation of students in Germany and cannot be derived from theoretical considerations alone.

Based on nationally representative and comprehensive survey data for the years 2003, 2006, and 2009, we empirically evaluate the effects of tuition fees on students' expenditure. Exploiting the natural experiment induced by the selective introduction of university tuition fees across federal states, we can identify causal effects under the assumption of an underlying common trend. Besides looking at overall expenditure only, we also consider relevant types of expenditure separately. The empirical results indicate that tuition fees changed students' spending behavior slightly overall by $4 \%$. When considering gender differences, the estimations show that women have decreased their expenditure by about $5 \%$, while effects for males are too small to become statistically significant. The results of the decomposition indicate that students most strongly saved expenditure for rent $(-38 \%)$.

To examine potential reasons for the overall moderate effects, we estimate the effects of tuition fees on a number of additional outcome variables that describe available resources, namely, weekly working hours, the probability of receiving financial support from parents or a partner, financial resources from parents, and the probability of taking out a loan. Tuition fees neither affected weekly working hours or the level of financial resources received from parents on average. However, the probability of receiving financial support from parents or a partner increased by 3 percentage points. Moreover, the probability of taking out a loan increased by 8 percentage points after the reform. By and large, students reacted to the reform by small changes of spending behavior and a slight increase of available financial resources.

The remainder of the paper is organized as follows: Section 2 provides details on the institutional background and reviews the related literature. The identification and estimation strategy as well as a description of the data are introduced in Section 3. Results of the estimation of the reform effects on the different outcomes considered are presented in Section 4 together with a number of robustness checks. The final section provides our conclusions.

\section{Institutional background and related literature}

In 2002, the German government enacted a law that guaranteed a free first course of studies for all students in Germany (gebührenfreies Erststudium). Subsequently, several states filed a constitutional law suit against this because education is administered by the federal states in Germany. By January 2005, the Federal Constitutional Court (Bundesverfassungsgericht) decided that federal states are free to grant permission to universities to charge tuition fees. Starting in the summer term of 2007, Baden-Wuerttemberg, Bavaria, Hamburg, Lower Saxony, and North Rhine-Westphalia introduced tuition fees, and Saarland and Hesse followed in the winter term 2007/2008 (see Table 8 in the Appendix for 
an overview). Although universities were not obliged to charge a uniform fee, most universities decided to charge the legal maximum of $€ 500$ (Hübner 2012). ${ }^{1}$ Fees were earmarked and had to be used for improving studying conditions and teaching.

Nevertheless, the introduction of tuition fees led to a controversial debate in Germany. The major concern was that tuition fees could discourage potential students, leading to a decrease in enrollment rates. A high proportion of individuals with a tertiary education is desirable because they have higher wages on average (thus increasing tax and social security revenues) and a lower unemployment probability than individuals with less education. Moreover, it contributes to the innovation potential of countries (Hoareau et al. 2013). On the individual level, the imposition of tuition fees increases the costs of studying, which may have adverse effects on university enrollment. However, the corresponding increase of available resources at universities may improve studying conditions and thus the probability of study success, mitigating potential adverse effects of higher costs.

The related results from the empirical literature for Germany are ambiguous. Without consideration of any further control variables (i.e., leaving out any effects due to potential composition differences of the student body across states or effects of other state-specific reforms in the German schooling and education system), Hübner (2012) estimated a slight decrease of student enrollment probability by 2.7 percentage points. Bruckmeier and Wigger (2014) used the same administrative data and estimation strategy but took compositional effects into account. Their findings indicated that tuition fees did not have a significant negative effect on enrollment. Similar results were established by Helbig et al. (2012) analyzing the willingness of high-school graduates between 2002 and 2008 to start studying. Their estimates showed that tuition fees had no effect on the willingness to study. Since tuition fees were only introduced in seven out of 16 federal states, students could have avoided paying fees by starting their studies in a non-fee state. Dwenger et al. (2012) investigated whether tuition fees systematically changed students' mobility for applicants at medical schools in Germany. Their results indicated that students from federal states with tuition fees were 2 percentage points $(-3 \%)$ less likely to apply in their home state after the introduction of fees. ${ }^{2}$

In addition, several authors have analyzed the financial burden of student loans (e.g., Schwartz and Finnie 2002) and related issues such as the determinants of the student loan take-up rate (e.g., Johnes 1994 and Gayle 1996, for the UK, Booji et al. 2012; Oosterbeek and van den Broek 2009), attitudes towards student debt (Davies and Lea 1995; Baum and O'Malley 2003; Haultain et al. 2010), or the optimal amount of student loans and their respective re-payments (Avery and Turner 2012; Baum and Schwartz 2006). Further studies describe different loan and cost-sharing systems between government and students (e.g., Chapman 2006; Greenaway and Haynes 2003; Barr 1993; Johnstone 2004) and the implications of different loan schemes for student enrollment (Ionescu 2009). Studies that look at tuition fees explicitly concentrate mainly on the consequences of increasing tuition fees for enrollment (e.g., Berger and Kostal 2002; Neill 2009) or the probability of late graduation (Garibaldi et al. 2012).

To the best of our knowledge, no study thus far has empirically examined the effects of tuition fees on students' actual financial situation. A few, mostly descriptive reports analyze students' financial situation in general (e.g., Vossensteyn 1999, for the Netherlands, Callender and Martin Kemp 2000, for the UK, James et al. 2007, for 
Australia, or Middendorff et al. 2013, for Germany). Ebens et al. (2011) analyze the effect of replacing supplementary grants for students in the Netherlands by loans. They emphasize the important role of financial support from parents. However, their results indicate that the supplementary grants induced a substantial substitution of parental support. Therefore, evaluating the effect of tuition fees on students' financial situation reveals new insights on the effects on students' economic situation regarding relevant types of expenditure and sources of income.

\section{Identification strategy and data}

\subsection{Identification of causal effects}

Our empirical analysis is based on the 17th, 18th, and 19th waves of the Social Survey, a representative longitudinal data set, conducted in the summer terms 2003, 2006, and 2009. The Social Survey is collected by the German Higher Education Information System (Deutsches Zentrum für Hochschul- und Wissenschaftsforschung, DZHW) on behalf of the German student union (Studentenwerk). It is funded and released by the German Federal Ministry of Education and Research (Bundesministerium für Bildung und Forschung, BMBF). Data have been collected in a regular cycle of 3 years since 1951. The Social Survey is a written survey that takes place in the summer term in German universities and universities of applied sciences. The representative sample refers to the population of German students and those who acquired university entrance qualification in Germany. Net response rates were $32 \%$ in the 2009 sample $(16,370$ observations), $31 \%$ in 2006 (16,590 observations), and $42 \%$ (21,424 observations) in 2003 . $^{3}$

Alongside rich data related to the course of studies and socio-demographic characteristics, it contains detailed information on the students' financial situation, income and expenditure, time use, and living situation. To identify causal effects of tuition fees on students' financial situation, we use the variation resulting from the fact that tuition fees were introduced only in some federal states. This implementation provides a natural experiment, where paying tuition fees can be assumed to be an exogenous treatment. Students are assigned into a treatment and a control group according to the university location. Those who studied in federal states that charged tuition fees in the summer term 2009 (Baden-Wuerttemberg, Bavaria, Hamburg, Lower Saxony, North Rhine-Westphalia, or Saarland, see Fig. 1) formed the treatment group; students who studied in states that did not charge fees formed the control group. ${ }^{4}$

For the empirical analysis, we excluded students of private universities and those who stated paying unusually high tuition fees (tuition fees of more than $€ 800$ or studying subscriptions of more than $€ 300$ ). Those who were exempted from paying fees were not considered either. Furthermore, we left out students aged 35 years or older and PhD students. In Germany, $\mathrm{PhD}$ students are often employed at the university and receive a salary. Students who are older are either long-term students with mandatory tuition fees or have worked before starting to study and may therefore have a different spending behavior than younger students. Overall, we thus used data on 43,212 students. ${ }^{5}$

Since our data provide information about the treatment and control group before and after the reform, a difference-in-differences approach can be applied that identifies the treatment effect if the common trend assumption is valid. A number of empirical studies have used the same identification strategy for the evaluation of the effects of 


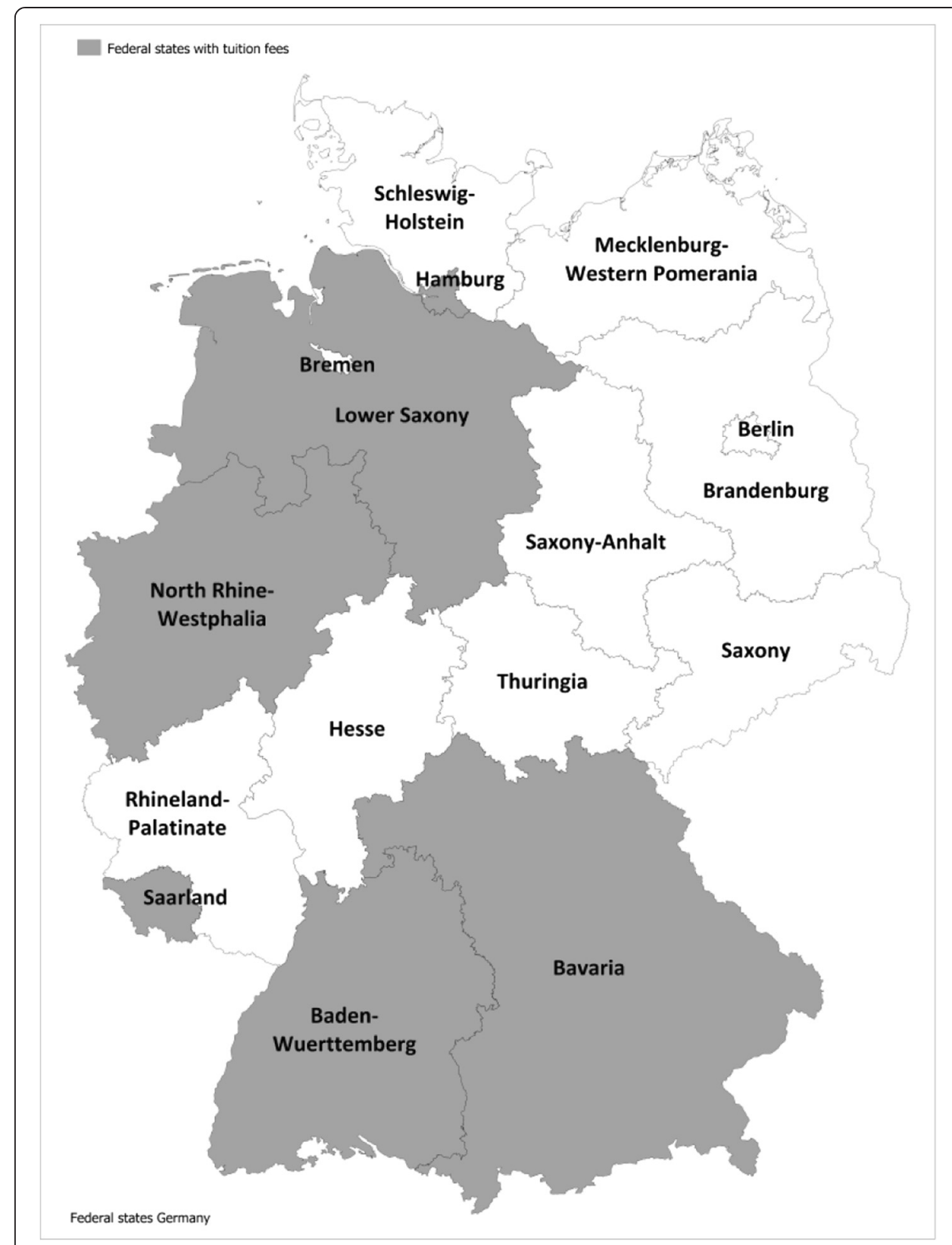

Fig. 1 German federal states charging tuition fees in 2009

tuition fees on other outcomes and have proven that the introduction of tuition fees in some of the German federal states provides a reasonable institutional setting for this estimation approach (e.g., Dwenger et al. 2012; Hübner 2012; Bruckmeier and Wigger 2014; Helbig et al. 2012). However, although the change in law can be clearly considered as an exogenous treatment, students may have avoided the treatment by starting their studies in a federal state that did not charge tuition fees. In that case, the allocation of treatment and control group would be not completely exogenous. Empirical studies indicate some changes in first-year student's mobility behavior, but reactions are only marginal (Dwenger et al. 2012). 
Table 1 reports the shares of students in our sample (pooled and according to gender) who graduated from high schools in a (non-)fee state and also studied in a (non-)fee state. If students wished to avoid paying fees, the share of those who obtained their qualification in a fee state and studied in a fee state would have decreased considerably from 2006 to 2009, while the share of those who studied in a non-fee state would have increased. Hardly any changes can be observed between 2006 and 2009, which supports our assumption that the treatment can be seen as exogenous and there are common trends regarding the compositional evolution of groups over time. Moreover, given that students had to pay tuition fees of $€ 500$ per semester at most universities in fee states, the second assumption of the difference-in-differences strategy representing a homogeneous treatment is accurate.

\subsection{Descriptive statistics}

Since we are interested in the effect of tuition fees on students' financial situation, we examine whether and to what extent paying tuition fees changed students' monthly expenditure. Expenditure includes all individual spending for rent, food, learning material, leisure, etc. excluding any tuition fees. Support from parents is included for comparability reasons. For example, some students receive greater financial support in cash from their parents but have to pay the rent themselves, while other students receive less support in cash but their parents pay the rent directly to a third party.

Table 1 Comparison of shares of high-school graduation state and state of studying

\begin{tabular}{|c|c|c|c|}
\hline & 2003 & 2006 & 2009 \\
\hline \multicolumn{4}{|l|}{ Pooled } \\
\hline \multicolumn{4}{|c|}{ Higher education entrance qualification obtained in a fee state } \\
\hline Studying in a fee state & $86 \%$ & $83 \%$ & $82 \%$ \\
\hline Studying in a fee-free state & $14 \%$ & $17 \%$ & $18 \%$ \\
\hline \multicolumn{4}{|c|}{ Higher education entrance qualification obtained in a fee-free state } \\
\hline Studying in a fee-free state & $81 \%$ & $81 \%$ & $84 \%$ \\
\hline Studying in a fee state & $19 \%$ & $19 \%$ & $16 \%$ \\
\hline \multicolumn{4}{|l|}{ Men } \\
\hline \multicolumn{4}{|c|}{ Higher education entrance qualification obtained in a fee state } \\
\hline Studying in a fee state & $86 \%$ & $83 \%$ & $84 \%$ \\
\hline Studying in a fee-free state & $14 \%$ & $17 \%$ & $16 \%$ \\
\hline \multicolumn{4}{|c|}{ Higher education entrance qualification obtained in a fee-free state } \\
\hline Studying in a fee-free state & $82 \%$ & $83 \%$ & $86 \%$ \\
\hline Studying in a fee state & $18 \%$ & $17 \%$ & $14 \%$ \\
\hline \multicolumn{4}{|l|}{ Women } \\
\hline \multicolumn{4}{|c|}{ Higher education entrance qualification obtained in a fee state } \\
\hline Studying in a fee state & $86 \%$ & $83 \%$ & $80 \%$ \\
\hline Studying in a fee-free state & $14 \%$ & $17 \%$ & $20 \%$ \\
\hline \multicolumn{4}{|c|}{ Higher education entrance qualification obtained in a fee-free state } \\
\hline Studying in a fee-free state & $80 \%$ & $79 \%$ & $83 \%$ \\
\hline Studying in a fee state & $20 \%$ & $21 \%$ & $17 \%$ \\
\hline
\end{tabular}

Source: 17th, 18th, and 19th Social Survey of the DZHW, own calculations 
Figure 2 illustrates the development of monthly mean expenditure for the treatment and control groups over time. Expenditure increases in both groups and is higher in the treatment group in all years. A likely reason for this is that most of the federal states of the control group are Eastern German states (Berlin, Brandenburg, Mecklenburg-Western Pomerania, Saxony, Saxony-Anhalt, and Thuringia), where living costs are lower on average than in the Western states (Kawka 2010). ${ }^{6}$ However, between 2006 and 2009, expenditure increased less in the treatment group, and the spending tends to converge across groups.

To characterize the analysis' groups further, Table 2 compares sample means of treatment and control groups before and after the reform for a selection of variables. The outcomes of interest comprise expenditure in total and for different aspects of living and studying. In addition, we consider sources of income by analyzing the effects on working time, financial support from parents and partner (dummy), financial resources from parents, and taking out a loan (incl. special loans for paying tuition fees; dummy). While expenditure for the rent was higher among students in the treatment group before the reform, after the reform, students in the control group spend on average more for the rent than students in the treatment group. The same is true for expenditure for food. A likely explanation for this may be changes in the living situation. While the share of students living with their parents (presumably the cheapest form of living) decreased in the control group, it slightly increased among the treatment group. Moreover, also the share of students living in student dormitories (with supposedly low rents) increased in the treatment group. In contrast, the share of students living alone-probably the most expensive form of living-decreased in the treatment group but increased slightly in the control group. This pattern might be interpreted as an indication of a worsening of the financial situation after the reform. However, expenditure for leisure, culture, and sports were in both time periods higher in the treatment group than in the control group.

Turning to the resources, weekly working hours increased in both groups and are neither in 2006 nor in 2009 significantly different. The share of students who received financial support from their parents or a partner (including payments to third parties) was marginally higher in the treatment group in 2006. It decreased over time in the control group, while it increased in the treatment group, but these changes were small.

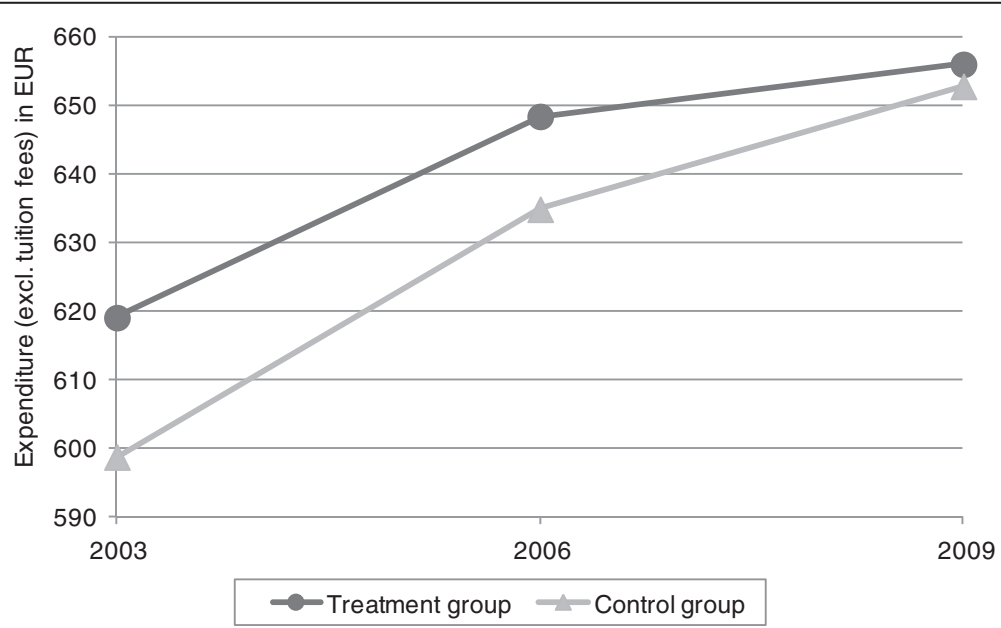

Fig. 2 Development of mean expenditure (excluding tuition fees) in EUR. Source: 17th, 18th, and 19th Social Survey of the DZHW, own calculations 
Table 2 Means of selected variables (by year and groups)

\begin{tabular}{|c|c|c|c|c|c|c|}
\hline & \multicolumn{3}{|l|}{2006} & \multicolumn{3}{|l|}{2009} \\
\hline & \multicolumn{2}{|l|}{ Means } & \multirow{2}{*}{$\begin{array}{l}P \text { value of the } t \\
\text { test/chi-squared } \\
\text { independence test }\end{array}$} & \multicolumn{2}{|l|}{ Means } & \multirow{2}{*}{$\begin{array}{l}P \text { value of the } t \\
\text { test/chi-squared } \\
\text { independence test }\end{array}$} \\
\hline & Control group & Treatment group & & Control group & Treatment group & \\
\hline \multicolumn{7}{|c|}{ Outcome variables } \\
\hline Expenditure (in EUR) & 631.53 & 646.17 & 0.003 & 645.82 & 650.43 & 0.369 \\
\hline Expenditure for the rent & 218.29 & 223.85 & 0.030 & 236.02 & 229.38 & 0.013 \\
\hline Expenditure for food & 133.06 & 136.45 & 0.022 & 144.50 & 142.64 & 0.223 \\
\hline Expenditure for clothes & 47.09 & 50.99 & 0.000 & 47.36 & 52.16 & 0.000 \\
\hline Expenditure for learning materials & 33.23 & 33.95 & 0.219 & 30.75 & 32.46 & 0.003 \\
\hline Expenditure for a car & 57.48 & 55.49 & 0.194 & 42.67 & 46.12 & 0.016 \\
\hline Expenditure for public transport & 19.94 & 22.03 & 0.000 & 23.38 & 24.19 & 0.212 \\
\hline Expenditure for medical insurance, medical fees & 32.25 & 28.85 & 0.000 & 36.73 & 35.66 & 0.254 \\
\hline Fees for telephone, internet & 38.10 & 37.32 & 0.118 & 30.53 & 29.82 & 0.107 \\
\hline Expenditure for leisure, culture, and sports & 52.11 & 57.24 & 0.000 & 53.88 & 58.02 & 0.000 \\
\hline Weekly working hours & 6.53 & 6.36 & 0.303 & 7.68 & 7.58 & 0.551 \\
\hline Financial support by parents or a partner & 0.884 & 0.898 & 0.008 & 0.865 & 0.91 & 0.000 \\
\hline Financial support by parents & 0.77 & 0.80 & 0.000 & 0.75 & 0.79 & 0.000 \\
\hline $\begin{array}{l}\text { Taking out a loan or special credit for paying } \\
\text { tuition fees }\end{array}$ & 0.02 & 0.02 & 0.973 & 0.03 & 0.11 & 0.000 \\
\hline \multicolumn{7}{|c|}{ Control variables } \\
\hline Male & 0.41 & 0.41 & 0.751 & 0.41 & 0.42 & 0.111 \\
\hline Foreign citizenship & 0.98 & 0.97 & 0.001 & 0.98 & 0.97 & 0.200 \\
\hline Having siblings & 0.85 & 0.87 & 0.000 & 0.85 & 0.86 & 0.183 \\
\hline
\end{tabular}


Table 2 Means of selected variables (by year and groups) (Continued)

\begin{tabular}{|c|c|c|c|c|c|c|}
\hline Number of semesters in university & 6.93 & 6.41 & 0.000 & 7.21 & 6.68 & 0.000 \\
\hline Age (in years) & 23.91 & 23.63 & 0.000 & 23.87 & 23.58 & 0.000 \\
\hline Apprenticeship before studying & 0.24 & 0.22 & 0.002 & 0.19 & 0.19 & 0.821 \\
\hline \multicolumn{7}{|l|}{ Father's position in the job } \\
\hline Not employed & 0.00 & 0.00 & 0.000 & 0.00 & 0.00 & 0.000 \\
\hline Low (reference) & 0.05 & 0.05 & & 0.05 & 0.05 & \\
\hline Medium & 0.52 & 0.46 & & 0.52 & 0.48 & \\
\hline High & 0.39 & 0.46 & & 0.39 & 0.44 & \\
\hline \multicolumn{7}{|l|}{ Mother's position in the job } \\
\hline Not employed & 0.02 & 0.03 & 0.000 & 0.02 & 0.02 & 0.041 \\
\hline Low (reference) & 0.07 & 0.09 & & 0.08 & 0.09 & \\
\hline Medium & 0.68 & 0.65 & & 0.67 & 0.67 & \\
\hline High & 0.23 & 0.23 & & 0.23 & 0.22 & \\
\hline \multicolumn{7}{|c|}{ Subgroup categories } \\
\hline Father university degree & 0.44 & 0.44 & 0.685 & 0.44 & 0.45 & 0.230 \\
\hline Mother university degree & 0.34 & 0.29 & 0.000 & 0.36 & 0.30 & 0.000 \\
\hline \multicolumn{7}{|c|}{ Additional variables } \\
\hline $\begin{array}{l}\text { Income (incl. payments of } \\
\text { parents or a partner } \\
\text { to third parties) (in EUR) }\end{array}$ & 723.22 & 743.53 & 0.000 & 766.08 & 780.05 & 0.020 \\
\hline Living at the parents' house & 0.21 & 0.23 & 0.000 & 0.19 & 0.26 & 0.000 \\
\hline
\end{tabular}


Table 2 Means of selected variables (by year and groups) (Continued)

\begin{tabular}{lccc}
\hline Living alone & 0.18 & 0.16 & 0.21 \\
Living in a shared flat & 0.49 & 0.45 & 0.15 \\
Living in a student dormitory & 0.11 & 0.12 & 0.43 \\
Number of observations & 5,755 & 7,618 & 0.12 \\
\hline
\end{tabular}

Note: means and $p$ values of the $t$ test for outcome and selected control variables are shown according to year and treatment group. Expenditure and income are measured in Euro, working hours in hours, and age in

years. Remaining variables are dummy variables. A $p$ value $\leq 0.001$ indicates that the means between treatment and control group differ significantly to the $1 \%$ level. Results of chi-squared-tests indicate that the distribution of treatment group and father's position in the job is independent neither in 2006 nor in 2009 (error probability $1 \%$ ). Source: 18th and 19th Social Survey of the DZHW, own calculations 
The average amount of financial resources from the parents available to the students in cash was higher in the treatment group than in the control group before and after the reform. In both groups, the average amount decreased slightly over time. A rarely used form of financing was the use of student loans in the time before the reform. In line with that, before introduction of tuition fees, only $2 \%$ of students took out a loan. After the reform, $11 \%$ of students of the treatment group took out a loan or a special loan for paying tuition fees. Only $3 \%$ of students among the control group took out a loan in 2009, and the group difference is significant in 2009.

With respect to socio-economic background variables, Table 2 illustrates that the shares of male students, students with foreign citizenship, and students with siblings were similar in the treatment and control group. Studying time was about half a semester higher in the control group compared to the treatment group. The average respondent in the sample was nearly 24 years old, while students in the control group were on average a few months older than students in the treatment group. Before the reform, nearly one quarter of students in the control group had completed an apprenticeship before starting studying (24\%); in the treatment group, the share was $22 \%$. In both groups, the share decreased to $19 \%$ in 2009. Concerning the parental background, Table 2 shows that the father's and mother's positions in the job were similarly distributed over groups and time. Only the share of students with fathers in high positions was higher among the treatment group.

\subsection{Estimation approach}

To estimate the effects of tuition fees on the outcomes of interest, we specified a number of difference-in-differences models of the following form (suppressing $i$ for the individual):

$$
Y=\beta_{0}+\beta_{1} T G+\beta_{2} \text { year }+\delta(T G \cdot \text { year })+X^{\prime} \gamma+u .
$$

$Y$ is the respective outcome of interest (expenditure, weekly working hours, receiving financial support from parents or partners, taking out a loan); TG is the treatment group dummy variable indicating that the individual studied in Baden-Wuerttemberg, Bavaria, Hamburg, Lower Saxony, North Rhine-Westphalia, or in the Saarland; year is the dummy variable for the time period after the reform (2009); and TG year is the interaction term. The parameter of interest is $\delta$, the difference-in-differences estimate that measures the effect of the introduction of tuition fees. The error term $u$ contains unobserved factors which affect the dependent variable.

The matrix $X$ denotes further control variables that we added to the model. These variables should account for the possibility that random samples within the treatment or control group have systematically different characteristics in the sample periods 2006 and 2009, indicated by parameter vector $\gamma$. Starting with the estimation of the model in Eq. (1) without any covariates, we subsequently added further control variables to specify the final model (see Tables 10, 11, and 12 in the Appendix for estimation results). In a first step (specification 2), we included a number of socio-demographic characteristics (gender, foreign citizenship, having siblings). In a second step, we include studying time in semesters and studying time squared. In specification 4, age (in years) and age squared is considered in addition. We augmented the model by a dummy variable that indicates whether the student has completed an apprenticeship before studying in specification 5. In specification 6, the parents' background is taken into account (dummy variables for father's or mother's position in the job). Finally, specification 7 includes 
dummy variables for the place of studying, i.e., regional control variables for federal states (reference for the treatment group is North Rhine-Westphalia, reference for the control group is Saxony). All these control variables are not affected by the introduction of tuition fees and can therefore be assumed to be exogenous.

All estimations were carried out for the pooled sample and for gender-separated samples. Moreover, to explore potential heterogeneity in the effects with respect to socio-economic status or background of the individuals, we considered four subgroups as well. Being aware of strong intergenerational patterns of university attendance, we estimated the effects of tuition fees for students with parents possessing tertiary education and those without. Finally, we took into account parents' position in their job (as an indicator of potential financial supporting ability) and distinguished between high and low positions.

\section{Empirical results}

\subsection{Effects on expenditure}

Table 3 summarizes the difference-in-differences estimates on the natural logarithm of total expenditure (excluding tuition fees) for the seven specifications (see above) for the full sam$\mathrm{ple}^{7}$ and for the gender-separated samples. The introduction of tuition fees decreased student's expenditure statistically significantly by $3.6 \%{ }^{8}$ The difference-in-differences estimator is very robust over the seven specifications. With regard to gender differences, the difference-in-differences estimate is smaller and insignificant for males. However, the estimates obtained for female students are larger (nearly $5 \%$ ) and statistically significant to the $1 \%$ level. Therefore, the negative overall effect seems to be driven by the effect for women.

In order to find out whether heterogeneous effects with respect to different types of expenditure exist, we divide total expenditure in several subcategories and estimate difference-in-differences models with different types of expenditure as dependent variables (Table 4). Each row contains the results of the "raw" difference-in-differences estimate (obtained from a regression on the treatment group, year indicator, and intercept) and the estimate obtained from the full specification with covariates. All estimations were done for the pooled sample and for the male and female sample separately.

The results show that the introduction of tuition fees led to a significant decrease in expenditure for the rent. Expressed as percentages, the corresponding declines amount to $45 \%$ overall and to even $52 \%$ for women. Furthermore, tuition fees reduced expenditure for food in the pooled sample and for women (by 7 and $8 \%$ ). The coefficient is, however, not significant for men. In contrast to that, tuition fees increased expenditure for the car (by $13 \%$ in the pooled sample and $14 \%$ for women). These patterns indicate that students (mainly women) have changed their living situation in response to the additional expenditure for tuition fees. Students whose parents live in the surrounding region of the university may decide to live together with their parents to avoid paying rent. Sharing a flat or living with parents may also explain the lower expenditure for food. Furthermore, it may hint to the different mobility behavior expressed by higher spending for a car. Individual mobility may become necessary for commuting between home and university. Expenditure for local public transport is unlikely to vary between students who live near to the university and those who commute from the surrounding region because fees for local public transport are usually obligatory for students. ${ }^{9}$ Therefore, variation in expenditure for public transport is not due to different expenditures for local public transport but stems probably 
Table 3 Difference-in-differences estimates (log. of total expenditure, 2006 and 2009)

\begin{tabular}{|c|c|c|c|c|c|c|c|c|}
\hline & & (1) & (2) & (3) & (4) & (5) & (6) & (7) \\
\hline \multirow[t]{3}{*}{ Pooled } & Coeff. & $-0.032^{* *}$ & $-0.032^{* *}$ & $-0.031^{* *}$ & $-0.032^{* *}$ & $-0.032^{* *}$ & $-0.031^{* *}$ & $-0.035^{* * *}$ \\
\hline & S.E. & $(0.013)$ & $(0.013)$ & $(0.013)$ & $(0.013)$ & $(0.013)$ & $(0.013)$ & $(0.013)$ \\
\hline & No. of obs. & 25,361 & 25,361 & 25,361 & 25,361 & 25,361 & 25,361 & 25,361 \\
\hline \multirow[t]{3}{*}{ Men } & Coeff. & -0.010 & -0.011 & -0.016 & -0.015 & -0.014 & -0.014 & -0.018 \\
\hline & S.E. & $(0.021)$ & $(0.021)$ & $(0.021)$ & $(0.020)$ & $(0.020)$ & $(0.020)$ & $(0.020)$ \\
\hline & No. of obs. & 10,445 & 10,445 & 10,445 & 10,445 & 10,445 & 10,445 & 10,445 \\
\hline \multirow[t]{3}{*}{ Women } & Coeff. & $-0.047^{* * *}$ & $-0.047^{* * *}$ & $-0.042^{* *}$ & $-0.045^{* * *}$ & $-0.044^{* * *}$ & $-0.044^{* * *}$ & $-0.047^{* * *}$ \\
\hline & S.E. & $(0.017)$ & $(0.017)$ & $(0.017)$ & $(0.016)$ & $(0.016)$ & $(0.016)$ & $(0.016)$ \\
\hline & No. of obs. & 14,916 & 14,916 & 14,916 & 14,916 & 14,916 & 14,916 & 14,916 \\
\hline \multicolumn{2}{|c|}{ Treatment group } & $\checkmark$ & $\checkmark$ & $\checkmark$ & $\checkmark$ & $\checkmark$ & $\checkmark$ & $\checkmark$ \\
\hline \multicolumn{2}{|c|}{ Year 2009} & $\checkmark$ & $\checkmark$ & $\checkmark$ & $\checkmark$ & $\checkmark$ & $\checkmark$ & $\checkmark$ \\
\hline \multicolumn{3}{|l|}{ Men } & $\checkmark$ & $\checkmark$ & $\checkmark$ & $\checkmark$ & $\checkmark$ & $\checkmark$ \\
\hline \multicolumn{3}{|c|}{ Citizenship } & $\checkmark$ & $\checkmark$ & $\checkmark$ & $\checkmark$ & $\checkmark$ & $\checkmark$ \\
\hline \multicolumn{3}{|l|}{ Siblings } & $\checkmark$ & $\checkmark$ & $\checkmark$ & $\checkmark$ & $\checkmark$ & $\checkmark$ \\
\hline \multicolumn{3}{|c|}{ Studying time (in semesters) } & & $\checkmark$ & $\checkmark$ & $\checkmark$ & $\checkmark$ & $\checkmark$ \\
\hline \multicolumn{3}{|c|}{ Studying time (in semesters) squared } & & $\checkmark$ & $\checkmark$ & $\checkmark$ & $\checkmark$ & $\checkmark$ \\
\hline \multicolumn{3}{|l|}{ Age } & & & $\checkmark$ & $\checkmark$ & $\checkmark$ & $\checkmark$ \\
\hline \multicolumn{3}{|c|}{ Age squared } & & & $\checkmark$ & $\checkmark$ & $\checkmark$ & $\checkmark$ \\
\hline \multicolumn{3}{|c|}{ Apprenticeship before studying } & & & & $\checkmark$ & $\checkmark$ & $\checkmark$ \\
\hline \multicolumn{3}{|c|}{ Father's position in the job } & & & & & $\checkmark$ & $\checkmark$ \\
\hline \multicolumn{3}{|c|}{ Mother's position in the job } & & & & & $\checkmark$ & $\checkmark$ \\
\hline \multicolumn{3}{|c|}{ Dummy variables for federal states } & & & & & & $\checkmark$ \\
\hline
\end{tabular}

Note: difference-in-differences estimates are displayed (obtained from ordinary least square estimations with the logarithm of expenditure as dependent variable). ${ }^{*}$ denotes statistical significance at the $10 \%$ level, ${ }^{* *}$ at the $5 \%$ level and ${ }^{* * *}$ at the $1 \%$ level. Source: 18th and 19th Social Survey of the DZHW, own calculations

from differences in expenditure for longer distance traveling, e.g., for traveling to parents or to friends. For women, tuition fees decreased expenditure for public transport by $16 \%$. A reason for this may be that women live more often with their parents, as expenditure for traveling home is lower in that case. The share of females in the treatment group living with their parents increased from $20 \%$ (2006) to about $24 \%$ (2009). In the control group, the corresponding share was about $18 \%$ in both years. For men, the introduction of tuition fees increased expenditure for public transport by $14 \%$ but the coefficient is only weakly significant.

In addition, Table 4 shows that tuition fees increase expenditure for clothes and for medical fees ${ }^{10}$ (significant to the $10 \%$ level). For men the increase in expenditure for medical fees is larger $(+13 \%)$; for women this effect is not significant. Tuition fees have also a negative effect on expenditure for leisure, culture and sports, which seems to be mainly driven by the effect for women ( $-8 \%$ overall and $-15 \%$ for women). Furthermore, for women tuition fees have a negative effect on expenditure for telephone and internet (-9\%). Again, this may also be linked to a change in the housing situation. Overall, results indicate that the rent is the type of expenditure that was strongly reduced by the introduction of tuition fee, and that women were slightly more affected than men.

To analyze potential effect heterogeneity with respect to the parental background, we divide the sample into students whose parents have and have no tertiary education and whose parents have a low position and a high position in their job (Table 5). The results of the four 
Table 4 Difference-in-differences estimates (log. of different types of expenditure, 2006 and 2009)

\begin{tabular}{|c|c|c|c|c|c|c|c|}
\hline \multirow[t]{2}{*}{ Expenditure for } & & \multicolumn{2}{|l|}{ Pooled } & \multicolumn{2}{|l|}{ Men } & \multicolumn{2}{|l|}{ Women } \\
\hline & & Raw & With covariates & Raw & With covariates & Raw & With covariates \\
\hline \multirow[t]{2}{*}{ Total } & Coeff. & $-0.032^{* *}$ & $-0.035^{* * *}$ & -0.010 & -0.018 & $-0.047^{* * *}$ & $-0.047^{* * *}$ \\
\hline & S.E. & $(0.013)$ & $(0.013)$ & $(0.021)$ & $(0.020)$ & $(0.017)$ & $(0.016)$ \\
\hline \multirow[t]{2}{*}{ Rent } & Coeff. & $-0.384^{* * *}$ & $-0.382^{* * *}$ & $-0.323^{* * *}$ & $-0.327^{* * *}$ & $-0.423^{* * *}$ & $-0.418^{* * *}$ \\
\hline & S.E. & $(0.042)$ & $(0.041)$ & $(0.069)$ & $(0.069)$ & $(0.051)$ & $(0.051)$ \\
\hline \multirow[t]{2}{*}{ Food } & Coeff. & $-0.069^{* *}$ & $-0.068^{* *}$ & -0.046 & -0.052 & $-0.087^{* *}$ & $-0.080^{* *}$ \\
\hline & S.E. & $(0.030)$ & $(0.029)$ & $(0.047)$ & $(0.047)$ & $(0.038)$ & $(0.037)$ \\
\hline \multirow[t]{2}{*}{ Clothes } & Coeff. & $0.058^{*}$ & $0.051^{*}$ & $0.086^{*}$ & 0.077 & 0.044 & 0.036 \\
\hline & S.E. & $(0.031)$ & $(0.031)$ & $(0.051)$ & $(0.051)$ & $(0.037)$ & $(0.038)$ \\
\hline \multirow[t]{2}{*}{ Learning materials } & Coeff. & -0.024 & -0.032 & -0.005 & -0.012 & -0.034 & -0.046 \\
\hline & S.E. & $(0.029)$ & $(0.029)$ & $(0.048)$ & $(0.048)$ & $(0.036)$ & $(0.036)$ \\
\hline \multirow[t]{2}{*}{ Car } & Coeff. & $0.154^{* * *}$ & $0.119^{* *}$ & $0.157^{*}$ & 0.101 & $0.145^{* *}$ & $0.127^{*}$ \\
\hline & S.E. & $(0.058)$ & $(0.057)$ & $(0.093)$ & $(0.091)$ & $(0.073)$ & $(0.072)$ \\
\hline \multirow[t]{2}{*}{ Public transport } & Coeff. & $-0.078^{*}$ & -0.031 & 0.072 & $0.130^{*}$ & $-0.181^{* * *}$ & $-0.146^{* * *}$ \\
\hline & S.E. & $(0.043)$ & $(0.043)$ & $(0.067)$ & $(0.067)$ & $(0.056)$ & $(0.055)$ \\
\hline \multirow{2}{*}{$\begin{array}{l}\text { Medical insurance, } \\
\text { medical fees }\end{array}$} & Coeff. & $0.091^{*}$ & $0.081^{*}$ & $0.157^{* *}$ & $0.118^{*}$ & 0.049 & 0.049 \\
\hline & S.E. & $(0.049)$ & $(0.044)$ & $(0.078)$ & $(0.070)$ & $(0.061)$ & $(0.056)$ \\
\hline \multirow{2}{*}{$\begin{array}{l}\text { Fees for telephone, } \\
\text { internet }\end{array}$} & Coeff. & -0.030 & -0.049 & 0.032 & 0.001 & $-0.072^{*}$ & $-0.082^{* *}$ \\
\hline & S.E. & $(0.032)$ & $(0.031)$ & $(0.052)$ & $(0.052)$ & $(0.040)$ & $(0.039)$ \\
\hline \multirow{2}{*}{$\begin{array}{l}\text { Leisure, culture, } \\
\text { sports }\end{array}$} & Coeff. & -0.058 & $-0.074^{* *}$ & 0.035 & 0.015 & $-0.124^{* * *}$ & $-0.135^{* * *}$ \\
\hline & S.E. & $(0.036)$ & $(0.036)$ & $(0.060)$ & $(0.061)$ & $(0.045)$ & $(0.045)$ \\
\hline \multicolumn{2}{|l|}{ No. of observations } & 25,361 & 25,361 & 10,445 & 10,445 & 14,916 & 14,916 \\
\hline
\end{tabular}

Note: difference-in-differences estimates are displayed (obtained from ordinary least square estimations with the logarithm of different expenditure as dependent variable). Next to the difference-in-differences estimate, the model includes a dummy variable for the treatment group and a dummy variable for 2009 (after the reform) as well as controls for socio-demographic background variables (gender, citizenship, indicator for having siblings, age, age squared), studying time (in semesters), studying time squared, a dummy variable that indicates whether the student has completed an apprenticeship before studying, dummy variables for the parents' position in their job, and dummy variables for federal states. * denotes statistical significance at the $10 \%$ level, ${ }^{* *}$ at the $5 \%$ level and ${ }^{* * *}$ at the $1 \%$ level. See text for further details. Source: 18 th and 19 th Social Survey of the DZHW, own calculations

subgroups considered show that the finding of the total sample is overall robust. However, the negative effect is larger for students with a lower economic background. While tuition fees decrease total expenditure of students whose parents have a high position in their job by about $5 \%$, the reduction is $10 \%$ for students whose parents have a low position in their job. Again, this result seems to be mainly driven by women. For males the effects are not statistically significant. Among women, the effect of paying tuition fees on total expenditure is $13 \%$ for women whose parents have a low position, but only $6 \%$ for women whose parents have a high position in their job (both significant to the $5 \%$ level). Hence, the results indicate that paying tuitions fees in Germany did lower expenditure of students at least for women, and that tuition fees did change the spending behavior of presumably more vulnerable students.

\subsection{Effects on financial resources}

The results on expenditure showed that tuition fees had overall moderate effects. One possible explanation might be that the additional average monthly cost of $€ 83.33$ due to tuition fees is too low to affect the students' budget constraints considerably. An alternative 
Table 5 Difference-in-differences estimates for different subgroups (log. of total expenditure, 2006 and 2009)

\begin{tabular}{|c|c|c|c|c|c|c|c|}
\hline \multirow[t]{2}{*}{ Sample } & & \multicolumn{2}{|l|}{ Pooled } & \multicolumn{2}{|l|}{ Men } & \multicolumn{2}{|l|}{ Women } \\
\hline & & Raw & $\begin{array}{l}\text { With } \\
\text { covariates }\end{array}$ & Raw & $\begin{array}{l}\text { With } \\
\text { covariates }\end{array}$ & Raw & $\begin{array}{l}\text { With } \\
\text { covariates }\end{array}$ \\
\hline \multirow[t]{3}{*}{ Total } & Coeff. & $-0.032^{* *}$ & $-0.035^{* * *}$ & -0.010 & -0.018 & $-0.047^{* * *}$ & $-0.047^{* * *}$ \\
\hline & S.E. & $(0.013)$ & $(0.013)$ & $(0.021)$ & $(0.020)$ & $(0.017)$ & $(0.016)$ \\
\hline & No. of obs. & 25,361 & 25,361 & 10,445 & 10,445 & 14,916 & 14,916 \\
\hline \multirow{3}{*}{$\begin{array}{l}\text { Parents have } \\
\text { no tertiary } \\
\text { education }\end{array}$} & Coeff. & -0.021 & -0.025 & 0.029 & 0.019 & $-0.056^{* *}$ & $-0.057^{* *}$ \\
\hline & S.E. & $(0.020)$ & (0.019) & $(0.031)$ & $(0.029)$ & $(0.025)$ & $(0.024)$ \\
\hline & No. of obs. & 12,230 & 12,230 & 5095 & 5095 & 7135 & 7135 \\
\hline \multirow{3}{*}{$\begin{array}{l}\text { Parents have } \\
\text { tertiary } \\
\text { education }\end{array}$} & Coeff. & $-0.041^{* *}$ & $-0.042^{* *}$ & -0.042 & $-0.048^{*}$ & $-0.041^{*}$ & $-0.040^{*}$ \\
\hline & S.E. & (0.018) & $(0.017)$ & $(0.029)$ & $(0.028)$ & $(0.023)$ & $(0.022)$ \\
\hline & No. of obs. & 13,051 & 13,051 & 5317 & 5317 & 7734 & 7734 \\
\hline \multirow{3}{*}{$\begin{array}{l}\text { Parents with } \\
\text { low position } \\
\text { in the job }\end{array}$} & Coeff. & $-0.091^{* *}$ & $-0.095^{* *}$ & -0.056 & -0.069 & $-0.121^{* *}$ & $-0.118^{* *}$ \\
\hline & S.E. & $(0.040)$ & (0.039) & $(0.064)$ & $(0.063)$ & $(0.052)$ & $(0.049)$ \\
\hline & No. of obs. & 2797 & 2797 & 1180 & 1180 & 1617 & 1617 \\
\hline \multirow{3}{*}{$\begin{array}{l}\text { Parents with } \\
\text { high position } \\
\text { in the job }\end{array}$} & Coeff. & $-0.045^{* *}$ & $-0.049^{* * *}$ & -0.035 & -0.046 & $-0.053^{* *}$ & $-0.054^{* *}$ \\
\hline & S.E. & (0.019) & $(0.018)$ & $(0.030)$ & $(0.029)$ & $(0.025)$ & $(0.024)$ \\
\hline & No. of obs. & 12,815 & 12,815 & 5,300 & 5,300 & 7,515 & 7,515 \\
\hline
\end{tabular}

Note:Difference-in-differences estimates are displayed obtained from ordinary least squares estimations. The dependent variable is the logarithm of expenditure. Specification 1 includes only the difference-in-differences estimate, a dummy variable for the treatment group, and a dummy variable for 2009 (after the reform). Specification 2 controls for socio-demographic background variables (gender, citizenship, indicator for having siblings, age, age squared), studying time (in semesters), studying time squared, a dummy variable that indicates whether the student has completed an apprenticeship before studying, dummy variables for the parents' position in their job, and dummy variables for federal states. Effects are calculated for different subgroups. * denotes statistical significance at the $10 \%$ level, ${ }^{* *}$ at the $5 \%$ level and ${ }^{* * *}$ at the $1 \%$ level. See text for further details. Source: 18th and 19th Social Survey of the DZHW, own calculations

explanation may be that students increased their disposable income, for example by taking out a loan, receiving more financial support from parents or partners, or increasing working hours. To study these effects, we estimated the impacts of tuition fees on these outcomes.

The corresponding results in Table 6 show that the introduction of tuition fees did not change weekly working hours. In contrast, tuition fees increased the share of students who receive financial support from parents or partners significantly by 3 percentage points. ${ }^{11}$ The share of students who are financially supported by their parents is high anyway (between 87 and $91 \%$ ); thus, this increase is relatively small. However, the tuition fees did not lead to an increase in the amount of financial resources in cash supported by the parents. ${ }^{12}$ Furthermore, Table 6 shows that tuition fees increased the probability of taking out a loan (including special loans that were introduced for paying tuition fees) by 8 percentage points. The effects of tuition fees on these four additional outcomes are very similar for men and women. The empirical results thus indicate that students increased their disposable budgets to some degree.

\subsection{Robustness checks}

In order to confirm the reliability of the results presented so far, we have conducted a number of robustness checks. These cover the influence of possible anticipation effects, the plausibility of the common trend assumption, and the sensitivity of the results with respect to alternative definitions of control groups and treatment groups. 
Table 6 Difference-in-differences estimates (further outcomes, 2006 and 2009)

\begin{tabular}{|c|c|c|c|c|c|c|c|}
\hline & & \multicolumn{2}{|l|}{ Pooled } & \multicolumn{2}{|l|}{ Men } & \multicolumn{2}{|l|}{ Women } \\
\hline & & Raw & $\begin{array}{l}\text { With } \\
\text { covariates }\end{array}$ & Raw & $\begin{array}{l}\text { With } \\
\text { covariates }\end{array}$ & Raw & $\begin{array}{l}\text { With } \\
\text { covariates }\end{array}$ \\
\hline \multirow[t]{3}{*}{ Weekly working hours } & Coeff. & 0.078 & -0.032 & -0.181 & -0.289 & 0.270 & 0.171 \\
\hline & S.E. & $(0.239)$ & $(0.228)$ & $(0.390)$ & $(0.371)$ & $(0.300)$ & $(0.288)$ \\
\hline & No. of obs. & 25,174 & 25,174 & 10,400 & 10,400 & 14,774 & 14,774 \\
\hline \multirow{3}{*}{$\begin{array}{l}\text { Financial support from } \\
\text { parents or a partner }\end{array}$} & Coeff. & $0.032^{* * *}$ & $0.033^{* * *}$ & $0.038^{* * *}$ & $0.037^{* * *}$ & $0.028^{* * *}$ & $0.029 * * *$ \\
\hline & S.E. & $(0.008)$ & $(0.008)$ & $(0.013)$ & $(0.012)$ & $(0.010)$ & $(0.010)$ \\
\hline & No. of obs. & 25,696 & 25,696 & 10,620 & 10,620 & 15,076 & 15,076 \\
\hline \multirow{3}{*}{$\begin{array}{l}\text { Financial resources } \\
\text { from parents (log) }\end{array}$} & Coeff. & 0.003 & 0.000 & 0.023 & -0.012 & -0.008 & -0.000 \\
\hline & S.E. & $(0.060)$ & $(0.055)$ & $(0.094)$ & $(0.086)$ & $(0.077)$ & $(0.071)$ \\
\hline & No. of obs. & 25,413 & 25,413 & 10,493 & 10,493 & 14,920 & 14,920 \\
\hline \multirow{3}{*}{$\begin{array}{l}\text { Taking out a loan } \\
\text { (incl. loan for } \\
\text { tuition fees) }\end{array}$} & Coeff. & $0.080^{* * *}$ & $0.079 * * *$ & $0.083^{* * *}$ & $0.081^{* * *}$ & $0.078^{* * *}$ & $0.078^{* * *}$ \\
\hline & S.E. & $(0.005)$ & $(0.005)$ & $(0.009)$ & $(0.009)$ & $(0.007)$ & $(0.007)$ \\
\hline & No. of obs. & 25,418 & 25,418 & 10,495 & 10,495 & 14,923 & 14,923 \\
\hline
\end{tabular}

Note: difference-in-differences estimates are displayed obtained from ordinary least squares estimations for the following outcome variables: weekly working hours, receiving financial support from the parents or a partner (yes/no, support in cash, payments to third parties and contribution to paying tuition fees), logarithm of financial resources from the parents (in cash), taking out a loan (incl. special loan for tuition fees, yes/no). Specification 1 includes only the difference-in-differences estimate, a dummy variable for the treatment group, and a dummy variable for 2009 (after the reform). Specification 2 controls for socio-demographic background variables (gender, citizenship, indicator for having siblings, age, age squared), studying time (in semesters), studying time squared, a dummy variable that indicates whether the student has completed an apprenticeship before studying, dummy variables for the parents' position in their job, and dummy variables for federal states. ${ }^{*}$ denotes statistical significance at the $10 \%$ level, ${ }^{* *}$ at the $5 \%$ level and ${ }^{* * *}$ at the $1 \%$ level. See text for further details. Source: 18 th and 19 th Social Survey of the DZHW, own calculations

\section{a. Anticipation effects}

Students may have anticipated the introduction of tuition fees and changed their behavior in advance because the law that allowed the charging of tuition fees was passed as early as 2005. Hence, this may bias the results when the years 2006 and 2009 are compared. To rule out these potential anticipation effects, we have reestimated Eq. (1) for the years 2003 and 2009. For the pooled sample, results concerning student expenditure are similar, indicating no anticipation effects in the 2006 to 2009 analysis sample (Table 7).

b. Common trend assumption

To check the plausibility of the identification assumption, namely whether the treatment and control groups followed a common trend before the introduction of tuition fees, we estimated a placebo difference-in-differences regression. Using the same specification as in Eq. (1), we refer to the years 2003 and 2006, i.e., for periods before tuition fees were introduced. Results are provided in the second panel of Table 7. The results of the difference-in-differences estimates are not statistically significant. Hence, we interpret this evidence in favor of the necessary assumption of a common trend to hold true.

c. Alternative control and treatment group definitions In some federal states, the allocation of students to the treatment group and the control group is ambiguous. To check the robustness of the results, we have estimated treatment effects using variations of treatment and control group definitions (results not displayed). Students in Hesse, for example, were assigned to the control group because they were not required to pay tuition fees in the summer 
Table 7 Difference-in-differences estimates (log. of total expenditure, 2003 and 2009 and 2003 and 2006)

\begin{tabular}{|c|c|c|c|c|c|c|c|}
\hline & \multicolumn{3}{|c|}{2003 and 2009} & \multicolumn{3}{|c|}{2003 and 2006} \\
\hline & & $(1)$ & $(2)$ & (3) & $(1)$ & (2) & (3) \\
\hline \multirow[t]{3}{*}{ Pooled } & Coeff. & $-0.041^{* * *}$ & $-0.041^{* * *}$ & $-0.031^{* *}$ & -0.004 & -0.005 & 0.002 \\
\hline & S.E. & $(0.013)$ & $(0.013)$ & $(0.013)$ & $(0.012)$ & $(0.012)$ & $(0.012)$ \\
\hline & No. of obs. & 29,847 & 29,847 & 29,847 & 31,818 & 31,818 & 31,818 \\
\hline \multirow[t]{3}{*}{ Men } & Coeff. & -0.003 & -0.003 & 0.002 & 0.014 & 0.013 & 0.018 \\
\hline & S.E. & $(0.020)$ & $(0.020)$ & $(0.019)$ & $(0.019)$ & $(0.019)$ & $(0.018)$ \\
\hline & No. of obs. & 13,014 & 13,014 & 13,014 & 13,725 & 13,725 & 13,725 \\
\hline \multirow[t]{3}{*}{ Women } & Coeff. & $-0.068^{* * *}$ & $-0.068^{* * *}$ & $-0.054^{* * *}$ & -0.017 & -0.018 & -0.010 \\
\hline & S.E. & $(0.017)$ & $(0.017)$ & $(0.017)$ & $(0.016)$ & $(0.016)$ & $(0.016)$ \\
\hline & No. of obs. & 16,833 & 16,833 & 16,833 & 18,093 & 18,093 & 18,093 \\
\hline \multicolumn{2}{|l|}{ Treatment group } & $\checkmark$ & $\checkmark$ & $\checkmark$ & $\checkmark$ & $\checkmark$ & $\checkmark$ \\
\hline \multicolumn{2}{|l|}{ Year 2009} & $\checkmark$ & $\checkmark$ & $\checkmark$ & $\checkmark$ & $\checkmark$ & $\checkmark$ \\
\hline \multicolumn{2}{|l|}{ Men } & & $\checkmark$ & $\checkmark$ & & $\checkmark$ & $\checkmark$ \\
\hline \multicolumn{2}{|l|}{ Citizenship } & & $\checkmark$ & $\checkmark$ & & $\checkmark$ & $\checkmark$ \\
\hline \multicolumn{3}{|c|}{ Studying time (in semesters) } & & $\checkmark$ & & & $\checkmark$ \\
\hline \multicolumn{3}{|c|}{ Studying time (in semesters) squared } & & $\checkmark$ & & & $\checkmark$ \\
\hline
\end{tabular}

Note: difference-in-differences estimates are displayed obtained from ordinary least squares estimations. The dependent variable is the logarithm of expenditure. Specification 1 includes only the difference-in-differences estimate, a dummy variable for the treatment group, and a dummy variable for 2009 (after the reform) or 2006 (placebo for after the reform). Specification 2 controls for socio-demographic background variables (gender, citizenship), studying time (in semesters), and studying time squared. ${ }^{*}$ denotes statistical significance at the $10 \%$ level, ${ }^{* *}$ at the $5 \%$ level and ${ }^{* * *}$ at the $1 \%$ level. See text for further details. Source: 17th, 18th, and 19th Social Survey of the DZHW, own calculations

term 2009. In the previous term (winter term 2008/2009), however, they still had to pay tuition fees. The estimation results excluding Hesse show slightly more pronounced effects: the negative effect of tuition fees on total expenditure is one percentage point higher in the pooled sample and in the sample of women. In addition, the effect for men becomes statistically significant.

Moreover, the treatment group in the city state of Hamburg differs from other states. Tuition fees were reduced from $€ 500$ to $€ 375$ in the winter term 2008/2009. Furthermore, students in Hamburg were offered the possibility of paying tuition fees after their studies. Estimation of our models excluding students from Hamburg, however, did not alter the results. Finally, Bavaria and Baden-Wuerttemberg offered a number of exceptions under which students were exempted from paying fees. For example, students with siblings studying in a fee state received a tuition waiver. Again, re-estimation excluding Bavarian and Baden-Wuerttemberg students indicated that results are very similar to those presented in Table 3. By and large, even with varying treatment and control group definitions, the obtained patterns for the effects of tuition fees on the considered outcomes maintain, and our results presented above can be interpreted as robust effects.

\section{Conclusions}

Politicians have justified the abolishment of tuition fees in Germany as a measure removing financial hurdles that prevent individuals from studying and improving equal opportunities. This paper has analyzed to what extent paying tuition fees of $€ 500$ per semester changed 
the financial situation of students. The empirical results indicate that the introduction of tuition fees changed students' spending behavior overall moderately. While expenditure of men was not affected, tuition fees decreased expenditure of women by $5 \%$. Nevertheless, the absolute magnitude of the decrease was relatively low given that women of the treatment group spent on average $€ 646$ per month, with a decrease of $5 \%$, thus amounting to $€ 32$. Analyzing the effect on different types of expenditure shows that tuition fees have a strong negative effect on expenditure for the rent for both men and women ( -39 and $-52 \%)$. Further results indicate that students, in particular women, seem to have changed their living situation in response to paying tuition fees.

More importantly from a political perspective, tuition fees did not affect students with lower education backgrounds. We found overall no effects for students whose parents have no tertiary education. While the effects for women whose parents have and have no tertiary education are very similar, tuition fees decreased expenditure for male students whose parents have tertiary education but not for men whose parents have no tertiary education. Concerning the parents' position in the job, we found more negative effects of tuition fees on expenditure for students whose parents have low position in the job, which is driven by the effect on women.

Moreover, our results show that tuition fees increased the probability of taking out a loan by 8 percentage points. This indicates that the special student loans that were introduced in Germany parallel to the introduction of tuition fees helped students to increase their available budget. However, students' main source of income is financial support from parents. Here, tuition fees induced an increase of the share of students receiving financial support from parents or partners but only to a small extent $(+3$ percentage points). Although this indicates that the additional financial burden intensified the required support from the parents slightly, empirical studies showed that this did not correspond to a change in university enrollment.

Tuition fees, therefore, did not substantially increase inequality across students in Germany. Social and education inequality rather result from selections earlier in life, for example because differences between children due to the parents' background already develop in early childhood and at school age (e.g., Hillmert and Jacob 2010; Cunha et al. 2006). In Germany, students are tracked into secondary school types typically at the age of ten. Schneider (2008), for example, finds that the social origin has a strong influence on this tracking decision. However, parental background has a smaller influence on dropping out of the high education track. This indicates that the importance of students' social origin decreases with age. Obviously, the most plausible reason for the moderate effect of tuition fees on students' expenditure may be the level of fees. A tuition fee of $€ 500$ per semester is equal to about $10 \%$ of monthly living costs (own calculation, in line with Helbig et al. 2012). Compared to other countries, tuition fees in Germany were therefore relatively low. In the academic year 2010/2011, US students had to pay a mean tuition fee of USD 13,297 at public universities in the USA (US Department of Education, National Center for Education Statistics, 2012). In Great Britain, first-year students had to pay a mean fee of 8,385 pounds per year in autumn 2012 (Ashley, 2012).

Therefore, the empirical results presented in this study do not unambiguously support the arguments of increased social inequality and severe financial reasons that were used for abolishing tuition fees in Germany. Consequently, raising tuition fees of a 
moderate amount may be a justifiable tool for ensuring university funding. This is particularly relevant in the light of the worldwide trend of increasing private contributions to the funding of higher education. Müller (2013) discusses several factors concerning the organization of tuition fees, which universities should take into account to increase acceptance for raising tuition fees. Among others, the utilization of fees should be transparent for students and should include all remaining charges. In most German universities, moreover, students had to pay tuition fees in addition to a general administrative charge. This may have been confusing and complicates the comparison of the universities cost-effectiveness (Müller 2013).

\section{Endnotes}

${ }^{1}$ Only in North Rhine-Westphalia and Bavaria did tuition fees vary between $€ 300$ and $€ 500$ at universities; in Hamburg, tuition fees were reduced from $€ 500$ to $€ 375$ in the winter term 2008/2009.

${ }^{2}$ Men reacted more strongly than women. Mitze et al. (2013) confirmed this stronger reaction of male students and showed further that the migration effects were mostly driven by short-distance migration over state borders.

${ }^{3}$ For further information, see www.sozialerhebung.de. Data can be accessed at Deutsches Zentrum für Hochschul- und Wissenschaftsforschung, DZHW, Hannover, Germany.

${ }^{4}$ Since Hesse had already abolished tuition fees before the summer term 2009, Hessian students are part of the control group.

${ }^{5}$ See Table 9 in the Appendix for the number of observations according to year and groups.

${ }^{6}$ Regional consumer prices developed very similar; between 2006 and 2009, the consumer price index increased on average by 4.9 percentage points in the treatment group and by 4.6 percentage points in the control group (German Statistical Office 2015).

${ }^{7}$ Table 10 in the Appendix provides details on the other estimated coefficients for the variables considered in the different specifications.

${ }^{8}$ The estimated coefficient indicates the expected increase in $\log Y$ after a oneunit increase in the respective covariate. Since we are interested in the exact expected increase of $Y$ itself, the coefficient has to be transformed accordingly: \% $\Delta \hat{y}=100 \cdot\left[\exp \left(\hat{\beta}_{i} \Delta x_{i}\right)-1\right]$.

${ }^{9}$ Most universities have agreements with (local) public transport companies and provide lower priced tickets for their students. However, paying the fees for the so-called semester ticket is obligatory for all students and part of the administration costs.

${ }^{10}$ Medical fees include fees for the own medical insurance, doctor's fees, and expenditure for drugs.

${ }^{11}$ Financial support from parents or a partner includes support in cash, payments to third parties, and contribution to paying tuition fees.

${ }^{12}$ Parents' payments for tuition fees are not included in this measure. Although the data contains information whether parents pay part of the tuition fees, it not known how much they actually pay. 


\section{Appendix}

Table 8 Overview of tuition fees in Germany

\begin{tabular}{lllll}
\hline Federal state & $\begin{array}{l}\text { Level of fees } \\
\text { (in EUR) }\end{array}$ & Date of decision & Introduced & Abolished \\
\hline Baden-Wuerttemberg & 500 & December 15, 2005 & Summer term 2007 & Summer term 2012 \\
Bavaria & Up to 500 & May 18, 2006 & Summer term 2007 & Winter term 2013/2014 \\
Hamburg & 375 & June 28, 2006 & Summer term 2007 & Winter term 2012/2013 \\
Hessen & 500 & October 05, 2006 & Winter term 2007/2008 & Winter term 2008/2009 \\
Lower Saxony & 500 & December 09, 2005 & Winter term 2006/2007 & Winter term 2014/2015 \\
North Rhine-Westphalia & Up to 500 & March 16, 2006 & Winter term 2006/2007 & Winter term 2011/2012 \\
Saarland & 500 & July 12, 2006 & Winter term 2007/2008 & Summer term 2010 \\
\hline
\end{tabular}

Note: In Lower Saxony and North Rhine-Westphalia, only first-year students had to pay tuition fees from the winter term 2006/2007, while older students had to pay from the summer term 2007. No tuition fees were charged in Berlin, Brandenburg, Bremen (only once in the winter term 2006/2007 for students who did not have their main residence in Bremen and for students who had studied for longer than 15 semesters), Mecklenburg-Western Pomerania, Rhineland-Palatinate, Saxony-Anhalt, Schleswig-Holstein, and Thuringia. "Date of decision": date on which the parliament of the federal state passed the law that says that tuition fees have to be charged; "Introduced": first term in which students had to pay tuition fees; "Abolished": first term in which students did not have to pay tuition fees anymore

Table 9 Number of observations (by year and group)

\begin{tabular}{lllll}
\hline & Year & & Sum \\
\cline { 2 - 4 } & 2003 & 2006 & 2009 & \\
\hline Control group & 7263 & 5755 & 5494 & 18,512 \\
Treatment group & 10,588 & 7618 & 6494 & 24,700 \\
Sum & 17,851 & 13,373 & 11,988 & 43,212 \\
\hline
\end{tabular}

Source: 17th, 18th, and 19th Social Survey of the DZHW, own calculations 
Table 10 OLS estimates (log. of total expenditure)

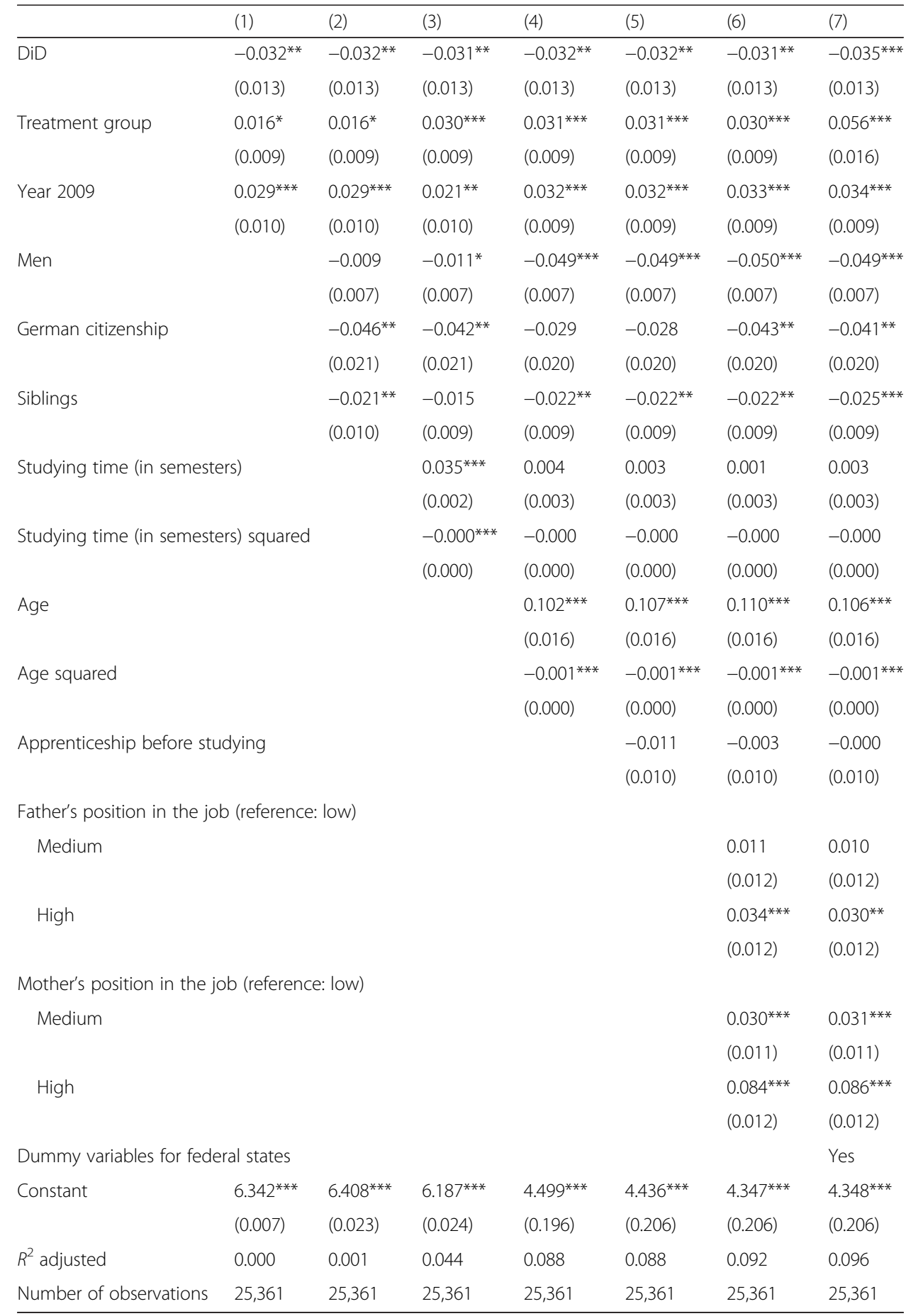

Note: displayed coefficients were obtained from ordinary least squares estimations. The dependent variable is the logarithm of expenditure. Source: 18th and 19th Social Survey of the DZHW, own calculations 
Table 11 OLS estimates for the subsample of male students (log. of total expenditure 2006 and 2009)

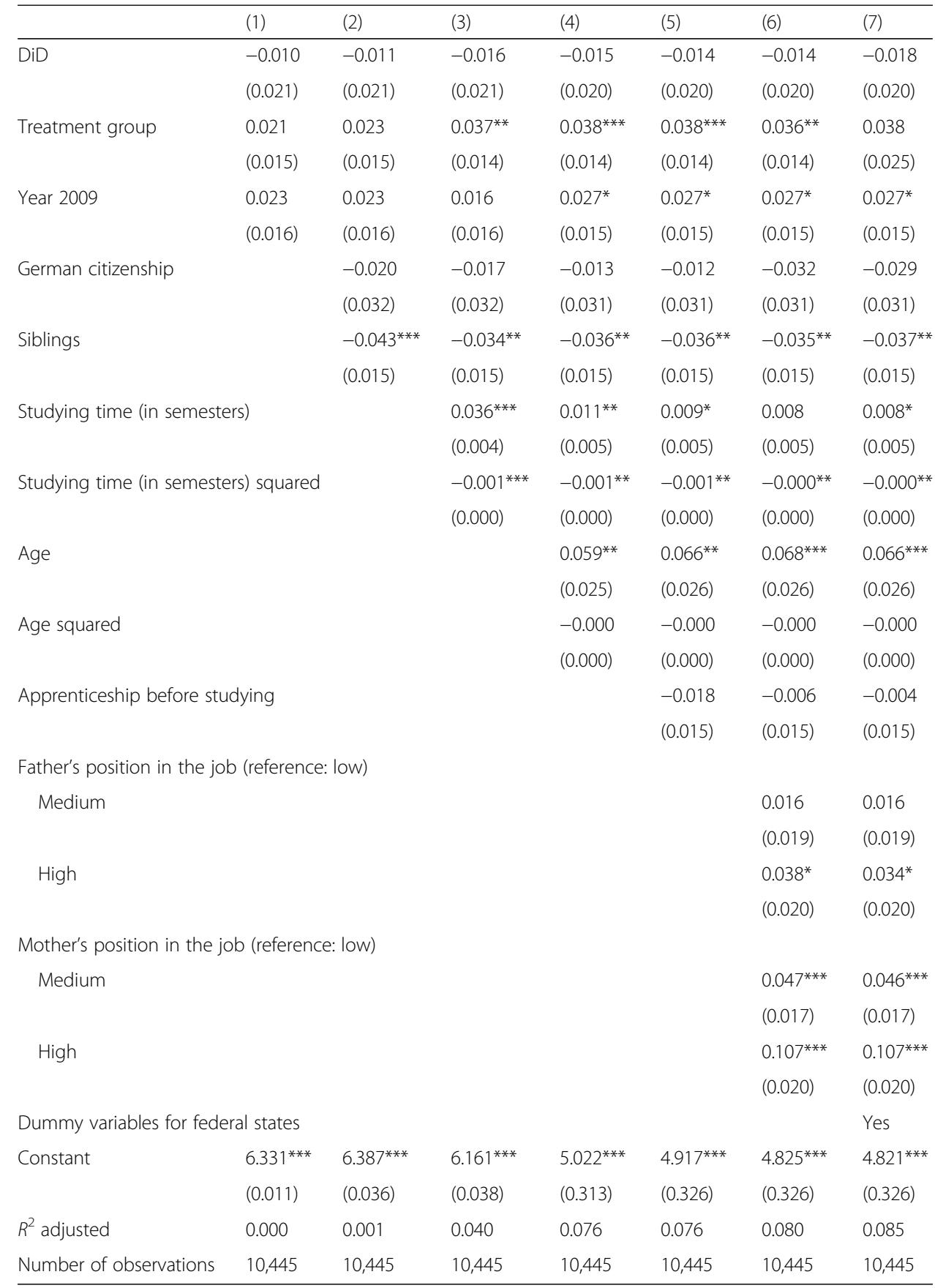

Note: displayed coefficients were obtained from ordinary least squares estimations for the subsample of male students. The dependent variable is the logarithm of expenditure. ${ }^{*}$ denotes statistical significance at the $10 \%$ level, ${ }^{* *}$ at the $5 \%$ level and ${ }^{* *}$ at the $1 \%$ level. Source: 18 th and 19 th Social Survey of the DZHW,

own calculations 
Table 12 OLS estimates for the subsample of female students (log. of total expenditure 2006 and 2009)

\begin{tabular}{|c|c|c|c|c|c|c|c|}
\hline & $(1)$ & $(2)$ & (3) & (4) & (5) & (6) & (7) \\
\hline \multirow[t]{2}{*}{ DiD } & $-0.047^{* * *}$ & $-0.047^{* * *}$ & $-0.042^{* *}$ & $-0.045^{* * *}$ & $-0.044^{* * *}$ & $-0.044^{* * *}$ & $-0.047^{* * *}$ \\
\hline & $(0.017)$ & $(0.017)$ & $(0.017)$ & $(0.016)$ & $(0.016)$ & $(0.016)$ & $(0.016)$ \\
\hline \multirow[t]{2}{*}{ Treatment group } & 0.012 & 0.012 & $0.025^{* *}$ & $0.027^{* *}$ & $0.027^{* *}$ & $0.026^{* *}$ & $0.072^{* * *}$ \\
\hline & $(0.012)$ & $(0.012)$ & $(0.011)$ & $(0.011)$ & $(0.011)$ & $(0.011)$ & $(0.020)$ \\
\hline \multirow[t]{2}{*}{ Year 2009} & $0.032^{* *}$ & $0.032^{* *}$ & $0.025^{* *}$ & $0.036^{* * *}$ & $0.036^{* * *}$ & $0.037^{* * *}$ & $0.039^{* * *}$ \\
\hline & $(0.013)$ & $(0.013)$ & $(0.012)$ & $(0.012)$ & $(0.012)$ & $(0.012)$ & $(0.012)$ \\
\hline \multirow{2}{*}{\multicolumn{2}{|c|}{ German citizenship }} & $-0.064^{* *}$ & $-0.061^{* *}$ & -0.040 & -0.039 & $-0.050^{*}$ & $-0.048^{*}$ \\
\hline & & $(0.028)$ & $(0.027)$ & $(0.026)$ & $(0.026)$ & $(0.027)$ & $(0.027)$ \\
\hline \multirow{2}{*}{\multicolumn{2}{|c|}{ Siblings }} & -0.006 & -0.003 & -0.013 & -0.013 & -0.014 & -0.018 \\
\hline & & $(0.012)$ & $(0.012)$ & $(0.012)$ & $(0.012)$ & $(0.012)$ & $(0.012)$ \\
\hline \multirow{2}{*}{\multicolumn{3}{|c|}{ Studying time (in semesters) }} & $0.033^{* * *}$ & -0.001 & -0.001 & -0.002 & -0.001 \\
\hline & & & $(0.003)$ & $(0.004)$ & $(0.004)$ & $(0.004)$ & $(0.004)$ \\
\hline \multirow{2}{*}{\multicolumn{3}{|c|}{ Studying time (in semesters) squared }} & $-0.000^{*}$ & -0.000 & -0.000 & -0.000 & -0.000 \\
\hline & & & $(0.000)$ & $(0.000)$ & $(0.000)$ & $(0.000)$ & $(0.000)$ \\
\hline \multirow{2}{*}{\multicolumn{2}{|c|}{ Age }} & & & $0.124^{* * *}$ & $0.126^{* * *}$ & $0.131^{* * *}$ & $0.125^{* * *}$ \\
\hline & & & & $(0.021)$ & $(0.022)$ & $(0.022)$ & $(0.022)$ \\
\hline \multirow[t]{2}{*}{ Age squared } & & & & $-0.001^{* * *}$ & $-0.001^{* * *}$ & $-0.001^{* * *}$ & $-0.001^{* * *}$ \\
\hline & & & & $(0.000)$ & $(0.000)$ & $(0.000)$ & $(0.000)$ \\
\hline \multirow{2}{*}{\multicolumn{2}{|c|}{ Apprenticeship before studying }} & & & & -0.004 & 0.001 & 0.005 \\
\hline & & & & & $(0.014)$ & $(0.014)$ & $(0.014)$ \\
\hline \multicolumn{8}{|c|}{ Father's position in the job (reference: low) } \\
\hline \multirow[t]{2}{*}{ Medium } & & & & & & 0.006 & 0.006 \\
\hline & & & & & & $(0.015)$ & $(0.015)$ \\
\hline \multirow[t]{2}{*}{ High } & & & & & & $0.031^{*}$ & $0.027^{*}$ \\
\hline & & & & & & $(0.016)$ & $(0.016)$ \\
\hline \multicolumn{8}{|c|}{ Mother's position in the job (reference: low) } \\
\hline \multirow[t]{2}{*}{ Medium } & & & & & & 0.015 & 0.017 \\
\hline & & & & & & $(0.014)$ & $(0.014)$ \\
\hline \multirow[t]{2}{*}{ High } & & & & & & $0.065^{* * *}$ & $0.070^{* * *}$ \\
\hline & & & & & & $(0.016)$ & $(0.016)$ \\
\hline \multicolumn{3}{|c|}{ Dummy variables for federal states } & & & & & Yes \\
\hline \multirow[t]{2}{*}{ Constant } & $6.350^{* * *}$ & $6.417^{* * *}$ & $6.200^{* * *}$ & $4.213^{* * *}$ & $4.189^{* * *}$ & $4.090^{* * *}$ & $4.101^{* * *}$ \\
\hline & $(0.009)$ & $(0.031)$ & $(0.032)$ & $(0.256)$ & $(0.270)$ & $(0.271)$ & $(0.271)$ \\
\hline$R^{2}$ adjusted & 0.00 & 0.001 & 0.047 & 0.098 & 0.098 & 0.101 & 0.105 \\
\hline Number of observations & 14,916 & 14,916 & 14,916 & 14,916 & 14,916 & 14,916 & 14,916 \\
\hline
\end{tabular}

Note: displayed coefficients were obtained from ordinary least squares estimations for the subsample of male students. The dependent variable is the logarithm of expenditure. * denotes statistical significance at the $10 \%$ level, ${ }^{* *}$ at the $5 \%$ level and *** at the $1 \%$ level. Source: 18 th and 19 th Social Survey of the DZHW, own calculations 


\section{Competing interests}

The IZA Journal of European Labour Studies is committed to the IZA Guiding Principles of Research Integrity. The authors declare that they have observed these principles.

\section{Acknowledgements}

The data used for the empirical analyses in this paper were provided by the Deutsches Zentrum für Hochschul- und Wissenschaftsforschung, DZHW, Hannover. We would like to thank the editor and the anonymous referees for helpful advise. We want to further thank Martina Kulik for her assistance in the preparation of the data. All interpretations and potential errors are the full responsibility of the authors.

Responsible editor: Sara de la Rica

\section{Author details}

${ }^{1}$ NIW Hannover, Königstr. 53, D-30175 Hannover, Germany. ${ }^{2}$ Leibniz Universität Hannover, Hannover, Germany. ${ }^{3}$ ZEW Mannheim, Mannheim, Germany. ${ }^{4}$ IZA Bonn, Bonn, Germany.

Received: 22 May 2015 Accepted: 7 January 2016

Published online: 29 March 2016

\section{References}

Ashley, D (2012): Average universitary tuition fee set up to rise to more than $£ 8,500$ a year. University and College Union July 16, 2012, accessed May 21, 2014, http://www.ucu.org.uk/6187

Avery C, Turner S (2012) Student loans: do college students borrow too much—or not enough? J Econ Perspect 26(1):165-192 Barr N (1993) Alternative funding resources for higher education. Econ J 103(418):718-728

Baum S, O'Malley M (2003) College on credit: how borrowers perceive their education debt. J Stud Financ Aid 33(3):6-19 Baum S, Schwartz S (2006) How much debt is too much? Defining benchmarks for manageable student debt. The College Board, New York

Berger MC, Kostal T (2002) Financial resources, regulation, and enrollment in US public higher education. Econ Educ $\operatorname{Rev} 21(2): 101-110$

Booji AS, Leuven E, Ooosterbeek H (2012) The role of information in the take-up of student loans. Econ Educ Rev 31(1):33-44

Bruckmeier K, Wigger BU (2014) The effects of tuition fees on transition from high school to university in Germany. Econ Educ Rev 41(3):14-23

Callender, C and Kemp, M (2000): Changing student finances: income, expenditure and take-up of student loans among full- and part-time higher education students in 1998/9. South Bank University, Department for Education and Employment, Research Report 213, Norwich.

Chapman B (2006) Income contingent loans for higher education: international reforms. In: Hanushek EA, Finis W (eds) Handbook of the economics of education, Vol. 2. Elsevier, Amsterdam, North Holland, pp 1435-1503

Cunha F, James H, Lance L, Dimitriy M (2006) Interpreting the evidence on life cycle skill formation. In: Hanushek Eric A, Finis W (eds) Handbook of the economics of education, Vol. 1. Elsevier, Amsterdam, North Holland, pp 698-812

Davies E, Lea SEG (1995) Student attitudes to student debt. J Econ Psychol 16(4):663-679

Die W (2008): Schwarz-Grüner Senat senkt Studiengebühren in Hamburg. Die Welt, June 18, 2008, accessed May 21, 2014, http://www.welt.de/welt_print/article2116860/Schwarz-Gruener-Senat-senkt-Studiengebuehren-in-Hamburg.html.

Dwenger N, Storck J, Wrohlich K (2012) Do tuition fees affect the mobility of university applicants? Evidence from a natural experiment. Econ Educ Rev 31(1):155-167

Ebens M, van Elk R, Dinand W, and Adam B (2011): The effect of the supplementary grant on parental contribution — an empirical analysis for the Netherlands, CPB Discussion Paper 187, The Hague.

Garibaldi P, Giavazzi F, Ichino A, Rettore E (2012) College cost and time to complete a degree: evidence from tuition discontinuities. Rev Econ Stat 94(3):699-711

Gayle V (1996) The determinants of student loan take-up in the United Kingdom: another gaze. Appl Econ Lett 3(1):25-27

German Statistical Office (2015): Verbraucherpreisindex für Deutschland - Lange Reihen ab 1948, monthly report, March 2015, Wiesbaden.

Greenaway D, Haynes M (2003) Funding higher education in the UK: the role of fees and loans. Econ J 113(485):F150-F166

Haultain S, Kemp S, Chernyshenko OS (2010) The structure of attitudes to student debt. J Econ Psychol 31(3):332-330

Helbig M, Baier T, Kroth A (2012) Die Auswirkungen von Studiengebühren auf die Studierneigung in Deutschland. Evidenz aus einem natürlichen Experiment auf Basis der HIS-Studienberechtigtenbefragung. Z Soziol 41(3):227-246

Hetze, P and Winde M (2012): Ländercheck - Lehre und Forschung im föderalen Wettbewerb. Stifterverband für die Deutsche Wirtschaft, September 2012, Essen.

Hillmert S, Jacob M (2010) Selections and social selectivity on the academic track: a life-course analysis of educational attainment in Germany. Res Soc Stratif Mobil 28(1):59-76

Hoareau C, Ritzen J, Marconi G (2013) Higher education and economic innovation, a comparison of European countries. IZA J Eur Labor Studies 2(1):1-24

Hübner M (2012) Do tuition fees affect enrollment behavior? Evidence from a "natural experiment" in Germany. Econ Educ Rev 31(6):949-960

Ionescu F (2009) The federal student loan program: quantitative implications for college enrollment and default rates. Rev Econ Dyn 12(1):205-231

James R, Bexley E, Devlin M, Marginson S (2007) Australian university student finances 2006: final report of a national survey of students in public universities. Australian Vice-Chancellors' Committee, Canberra, A.C.T

Johnes G (1994) The determinants of student loan take-up in the United Kingdom. Appl Econ 26(10):999-1005

Johnstone DB (2004) The economics and politics of cost sharing in higher education: comparative perspectives. Econ Educ Rev 23(4):403-410 
Kawka, R (2010). Regionale Preisunterschiede in den alten und neuen Ländern. Aktuelle Forschungsergebnisse - ifo Dresden berichtet, 2/2010, Dresden.

Middendorff, Elke, Beate Apolinarski, Jonas Poskowsky, Maren Kandulla, and Nicolai Netz (2013): Die wirtschaftliche und soziale Lage der Studierenden in Deutschland 2012. 20. Sozialerhebung des Deutschen Studentenwerks durchgeführt durch das HIS-Institut für Hochschulforschung. Eds: Bundesministerium für Bildung und Forschung, Berlin.

Mitze T, Burgard C, and Alecke B (2013): The tuition fee "shock": analysing the response of first-year students to a spatially discontinuous policy change in Germany. Papers in Regional Science, online first, DOI: 10.1111/pirs.12067.

Müller, U. (2013): Studienbeiträge - vorerst gescheitert?, in: Winfried Benz, Jürgen Kohler, Klaus Landfried (Ed.): Handbuch Qualität in Studium und Lehre (C/4/2), Berlin (Raabe), 1-38.

Neill C (2009) Tuition fees and the demand for university places. Econ Educ Rev 28(5):561-570

Oosterbeek H, van den Broek A (2009) An empirical analysis of borrowing behavior of higher education students in the Netherlands. Econ Educ Rev 28(2):170-177

Schneider T (2008) Social inequality in educational participation in the German school system in a longitudinal perspective: pathways into and out of the most prestigious school track. Eur Sociol Rev 24(4):511-526

Schwartz S, Finnie R (2002) Student loans in Canada: an analysis of borrowing and repayment. Econ Educ Rev 21(5):497-512

U.S. Department of Education, National Center for Education Statistics (2012): Digest of education statistics, 2011 (NCES 2012-001), Chapter 3. Accessed October 13, 2013. http://nces.ed.gov/fastfacts/display.asp?id=76.

Universität Hamburg, Campus Center (n.y.a.): Studiengebühren. Accessed May 21, 2014. http://www.uni-hamburg.de/ campuscenter/studienorganisation/beitraege-gebuehren/studiengebuehren.html.

Vossensteyn H (1999) The financial situation of students in the Netherlands. Eur J Educ 34(1):59-68

\section{Submit your manuscript to a SpringerOpen ${ }^{\circ}$} journal and benefit from:

- Convenient online submission

- Rigorous peer review

- Immediate publication on acceptance

- Open access: articles freely available online

- High visibility within the field

- Retaining the copyright to your article

Submit your next manuscript at $>$ springeropen.com 